\title{
39. SUBSIDENCE RECORD OF EARLY-STAGE CONTINENTAL COLLISION, ERATOSTHENES PLATFORM (SITES 966 AND 967) ${ }^{1}$
}

\author{
Brian M. Whiting ${ }^{2}$
}

\begin{abstract}
A major thematic objective of Ocean Drilling Program Leg 160 drilling was an improved understanding of the processes involved in the initial stages of continental collision. The Eratosthenes platform is hypothesized to be a fragment of thinned North African crust that is about to be subducted beneath Cyprus. Incipient subduction appears to be accompanied by extensive normal faulting, indicating that the Eratosthenes platform is undergoing breakup. Drilling at Sites 965-968 was aimed primarily at documenting the timing and nature of the subsidence and breakup. Using shipboard paleontologic and physical properties data, supplemented with postcruise age refinements, paleobathymetric estimates, and porosity vs. depth determinations, I present quantitative decompacted subsidence histories for Sites 966 and 967, which are located on or immediately adjacent to the Eratosthenes platform. Taken together, the subsidence results are consistent with a model in which the Eratosthenes platform is a part of North African passive margin that underwent exponentially decreasing thermal subsidence since at least early Cretaceous time, was uplifted during the late Oligocene or early Miocene, and then began a phase of rapid tectonic subsidence by late Miocene time, which has continued to the present day. The overall interpretation of the subsidence history presented here is that the Eratosthenes platform represents a thinned promontory of North African lithosphere that is now in the early stages of tectonic contact with the Eurasian plate. Breakup and subsidence since Miocene time may be related to bending stresses on the North African lithosphere associated with collision.
\end{abstract}

\section{INTRODUCTION}

A major goal of Leg 160 was to decipher the processes involved in the early stages of continent-continent collision. The site of this investigation has commonly been referred to as the Eratosthenes seamount (Fig. 1), which is likely a continental fragment (based on results presented here and elsewhere in this volume) and will be referred to herein as the Eratosthenes platform. The present-day tectonic setting of the Eratosthenes platform (Fig. 1) is dominated by collisional tectonics, with impingement of the Eratosthenes platform upon the Cyprus active margin, breakup of the platform, and incipient subduction of the Eratosthenes platform down the Cyprus trench, with a significant strike-slip component (Robertson and Xenophontos, 1993; Piper et al., 1996; Robertson et al., 1995b; Robertson et al., 1996). The early stages of hard collision are not well represented by modern analogues and are not well preserved in the ancient record, so the breakup and underthrusting of the Eratosthenes platform beneath Cyprus represents an opportunity to document these processes. The goal of this paper is to address fundamental objectives of Leg 160 by providing a quantitative subsidence and uplift history of Sites 966 and 967, which are located on the Eratosthenes platform (Fig. 1).

\section{Regional Setting}

The easternmost Mediterranean was formed by rifting of the north margin of Gondwana in the Triassic (Garfunkel and Derin, 1984). The eastern Mediterranean represents the last remnant of Neotethys that is in the final stages of closure associated with the diachronous collision of the African and Eurasian plates (Fig. 1). The Eratosthenes platform is generally interpreted to be a carbonate platform built on a rifted continental fragment (Robertson et al., 1997). Oceanic crust was formed in much of the easternmost Mediterranean by the late

${ }^{1}$ Robertson, A.H.F., Emeis, K.-C., Richter, C., and Camerlenghi, A. (Eds.), 1998. Proc. ODP, Sci. Results, 160: College Station, TX (Ocean Drilling Program).

${ }^{2}$ Department of Geology, College of William and Mary, Williamsburg, VA 23187, U.S.A. (Present address: Department of Geology, Central Washington University, Ellensburg, WA 98926, U.S.A.) bmw@gis.cwu.edu
Triassic, as represented by "accreted" fragments in southwestern Cyprus (Mamonia Complex), southwestern Turkey (Mamonia Complex), and northern Syria (Baer-Bassit) (Robertson et al., 1991). During the Cretaceous, relative motion of the African and Eurasian plates became convergent; in response to this regional plate convergence, subduction began within the southerly eastern Mediterranean ocean basin, leading to formation of the Troodos ophiolite complex by

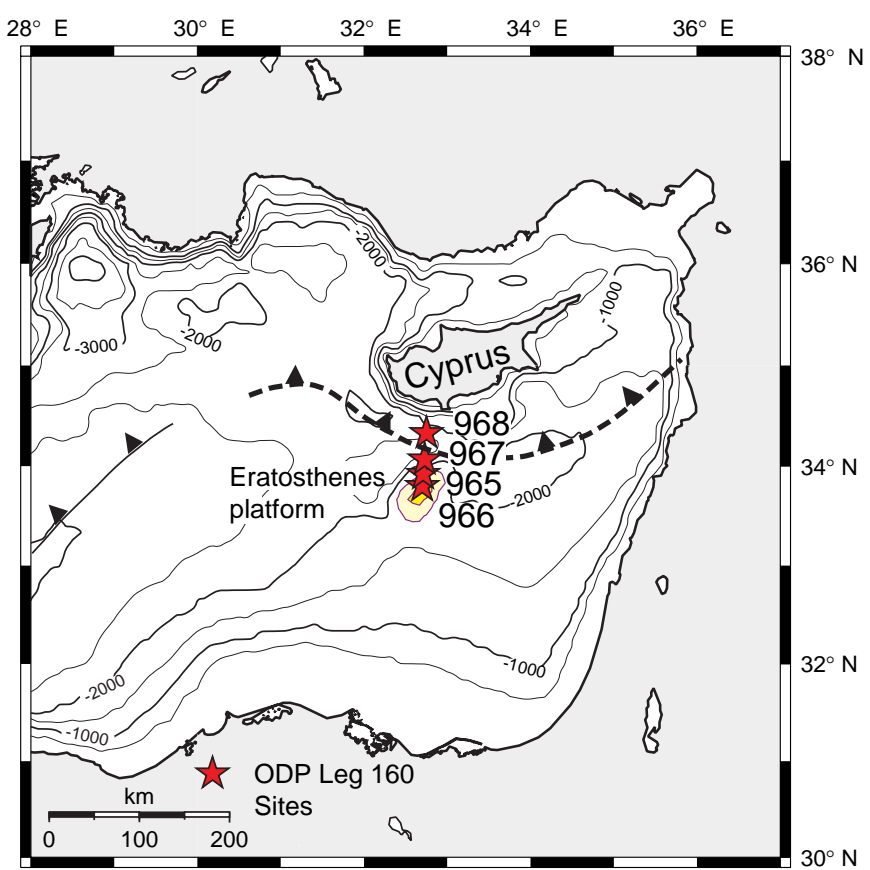

Figure 1. Site location map, bathymetry (in meters below sea level), and tectonic overview of Eratosthenes platform. Barbed line indicates present location of convergent margin. 
back-arc spreading (Robertson and Xenophontos, 1993). The associated subduction zone probably dipped northward and was located to the south of Cyprus (Robertson et al., 1997). On the basis of paleomagnetic studies of the Troodos ophiolite, much of Cyprus underwent counterclockwise rotation as a discrete microplate during the Late Cretaceous through early Eocene (Clube et al., 1985; Morris et al., 1990; Morris, 1996). Beginning in at least the early Miocene, remaining easternmost Mediterranean oceanic crust to the south of Cyprus began northward subduction, and the North African plate, including the Eratosthenes platform, began its final northward drift towards Cyprus (Dewey and Şengör, 1979; Dercourt et al., 1993). Thus by early Miocene time, southern Cyprus was located on the leading edge of what had by then become the Eurasian plate. Bathymetrically, the Eratosthenes platform is a large, subrectangular, elevated feature in the Mediterranean Sea south of Cyprus (Fig. 1). A regional magnetic anomaly (Truffert et al., 1993) only partly coincides with the bathymetric expression of the Eratosthenes platform, and gravity data indicate lack of compensation of the Eratosthenes platform (Truffert et al., 1993). Pre-Leg 160 work suggests that the Eratosthenes platform is in the process of collision with the Cyprus active margin to the north (Robertson, 1990; Woodside, 1991; Robertson, 1994; Robertson et al., 1995b). In terms of subsidence history, an implication of the above tectonic summary is that subsidence of the Eratosthenes platform sites should follow an exponentially decaying trend that is characteristic of cooling of passive margins (McKenzie, 1978), possibly overprinted by more rapid subsidence that is characteristic of convergent-margin tectonics (Whiting and Thomas, 1994).

\section{DATA AND METHODS}

Subsidence or geohistory curves (van Hinte, 1978; Steckler and Watts, 1978) are used to portray depression (or uplift) of a reference surface through time. An essential step in subsidence calculations is quantitative decompaction of the sedimentary column between each dated horizon. Ideally, the reference horizon portrayed should be crystalline basement, but this is not always possible. Lacking local seismic estimates or drilled determinations of depth to basement for the Eratosthenes platform sites, I assumed a reference surface $100 \mathrm{~m}$ below the base of the deepest holes at Site 967, which penetrated rocks of the greatest age. For Site 966, I used a reference surface that is based on a total thickness of sediments comparable to that of Site 967. For both sites, I assumed that the reference surface represented the Hauterivian/Barremian age of the onset of regional thermal subsidence. The effect of errors in the depth or age of the assumed reference surface would be to alter the starting point (origin) of the computed subsidence curves rather than the overall shape of the curves; an incorrect selection of reference horizon would also systematically affect decompaction calculations (see below).

Data required for subsidence calculations include numerical ages of selected horizons, estimated paleobathymetry of the horizons (from facies and paleontologic data), lithology, and an estimate of the compaction history of the sediment column. Originally, tectonic subsidence calculations ("backstripping") involved removal of sediment and water load using an assumption of Airy isostasy (Steckler and Watts, 1978; Sclater and Christie, 1980). Although Airy isostasy is a mathematical convenience, it is not rheologically realistic for thermally old lithosphere or for known flexural problems. An alternative is to portray decompacted, water-filled depth to basement through time ("total subsidence"); this approach follows Whiting et al. (1994), Whiting and Thomas (1994), and Thomas and Whiting (1996) and has the advantage of being sensitive to sedimentologic and isostatic inputs. Total subsidence curves, which were used as an intermediate step in Airy backstripping calculations by Sclater and Christie (1980), are thus used here because of the inappropriateness of assuming Airy isostasy at a convergent margin. Flexural backstripping could provide an alternative approach, but requires major assumptions about the long-term mechanical and thermal behavior of the lithosphere that cannot be justified with available data from the Eratosthenes platform region.

\section{Porosity vs. Depth}

To correctly define subsidence rates, it is necessary to estimate how the sediment has changed thickness as a function of time and thus correct the present-day sediment thicknesses for effects of compaction. Typically, downhole change in porosity is modeled as an exponential of the form:

$$
\phi=\phi_{0} \mathrm{e}^{-\mathrm{cz}},
$$

where $\phi$ is porosity at depth $\mathrm{z}$ in meters, $\phi_{0}$ is the initial porosity of the sediment, and $\mathrm{c}$ describes the rate of porosity decrease with depth (Athy, 1930; Perrier and Quiblier, 1974; Schmoker and Halley, 1982; Doglioni and Goldhammer, 1988) Although geophysical logging was performed at Sites 966 and 967, large variations in caliper (and thus borehole) diameter (Emeis, Robertson, Richter, et al., 1996) made neutron porosity measurements unreliable. Therefore, composite shipboard index-properties data for Sites 966 and 967 provided the most comprehensive and reliable basis to estimate $\phi_{0}$

Holes 967A\&E IP Data

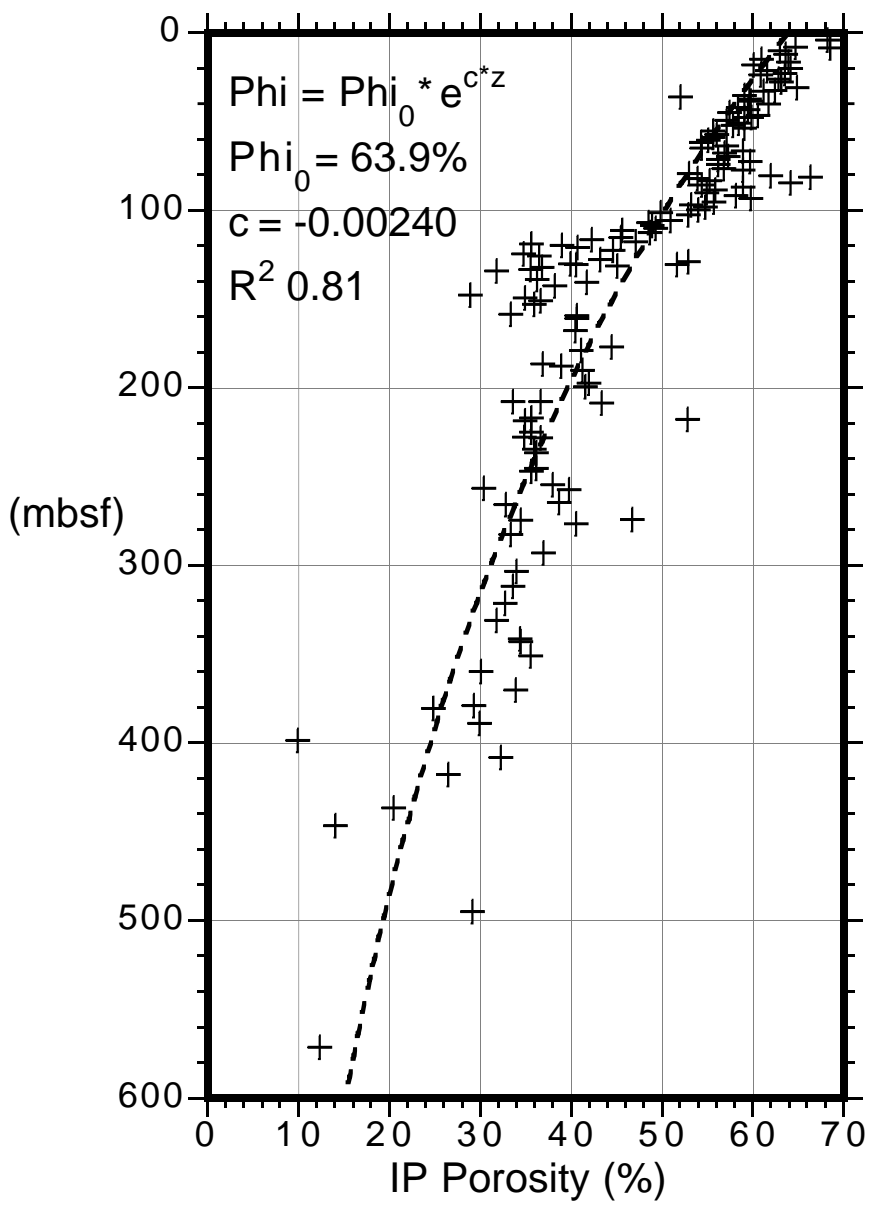

Figure 2. Site 967 index properties data and least-squares exponential fit. Exponential fit was obtained by using built-in routines of the Kaleidagraph plotting and statistics program. 


\section{Site 967}

\section{Paleobathymetry}

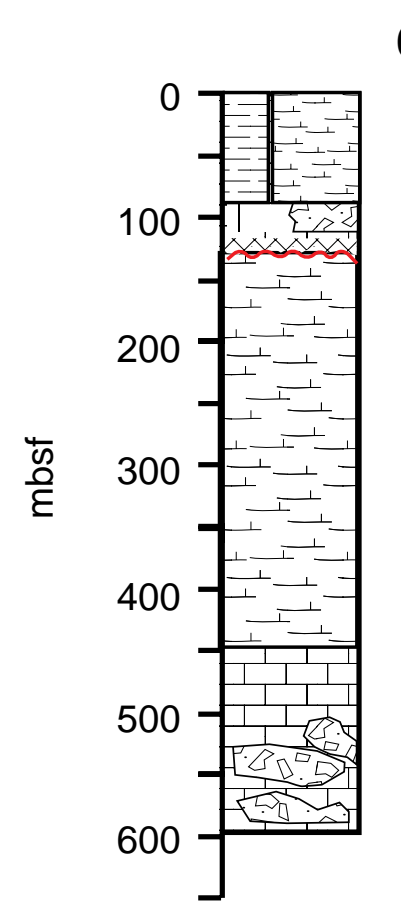

Age

Explanation
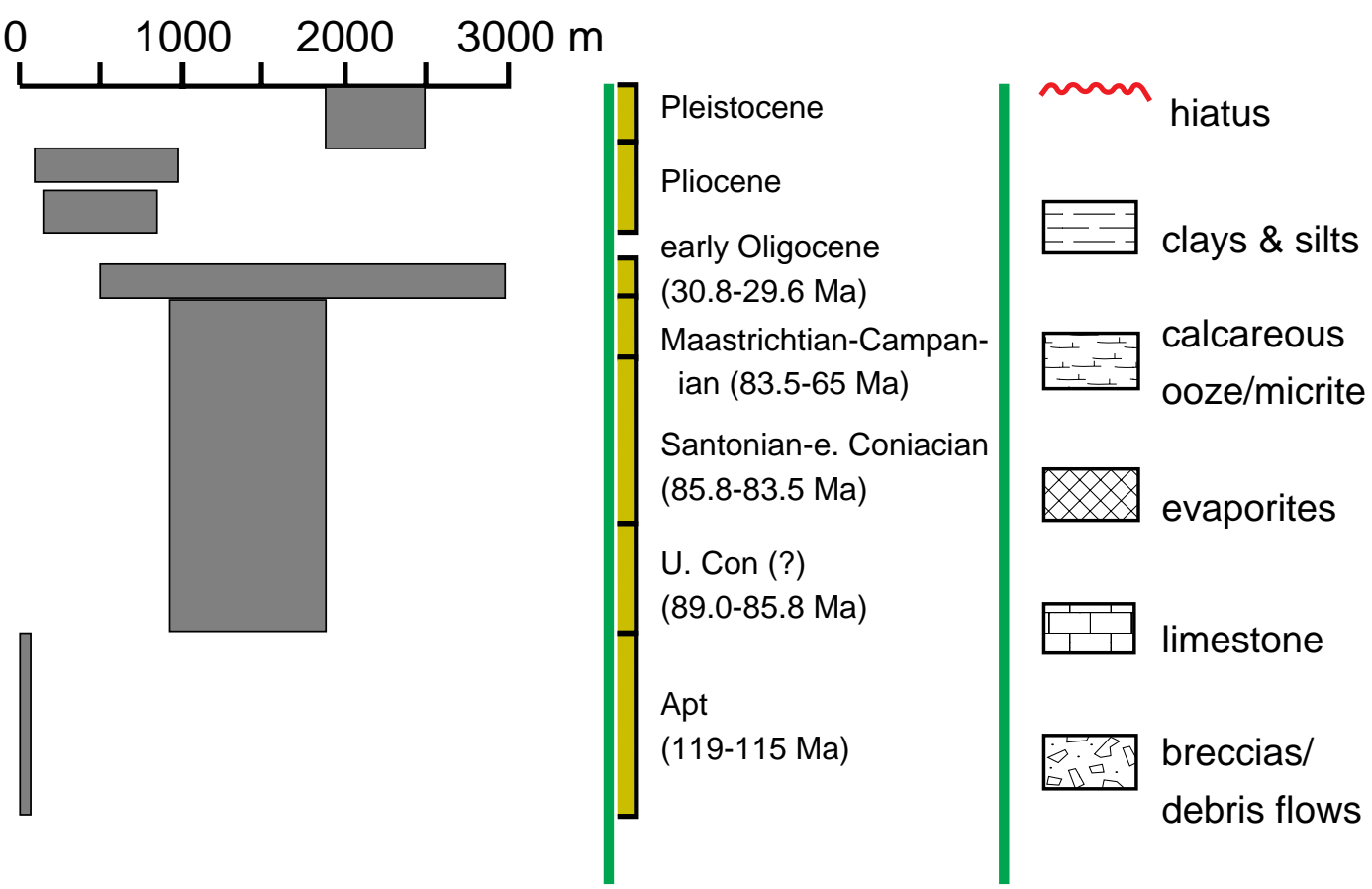

Figure 3. Data summary for Site 967, showing age, paleobathymetry, and lithology.

and c. Because of the greater depth of penetration, Site 967 was selected for downhole porosity modeling, and standard least-squares curve-fitting methods were used to determine an overall best-fitting porosity-depth curve (Fig. 2). Existing compaction literature indicates that important lithology-dependent differences in compaction behavior exist; however, index properties data were not sufficient to permit determination of individual porosity-depth relationships for each lithology. Based on broad similarities in depositional history, I assumed that the porosity-depth relationship obtained for Site 967 is also valid for Site 966.

\section{Biostratigraphy and Paleobathymetry}

Numerical ages for Pliocene and Quaternary sediments (Figs. 3, 4) are based on shipboard biostratigraphy, which were based on calcareous nannofossils and planktonic foraminifers (Emeis, Robertson, Richter, et al., 1996). Pliocene-Holocene paleobathymetry estimates (Figs. 3, 4) are based on benthic foraminiferal studies by S. Spezzaferri and I. Premoli-Silva (pers. comm., 1996; Premoli Silva et al., Chap. 30, this volume). Facies evidence and benthic foraminifer data are consistent with regard to water depth information; for example, the shallow-water origin interpreted for limestones recovered from Hole $966 \mathrm{~F}$ between $\sim 68$ and 298 mbsf (Emeis, Robertson, Richter, et al., 1996) is confirmed by the presence of shallow-water benthics in the interval 269.4-279 mbsf (S. Spezzaferri, pers. comm., 1996). Postcruise biostratigraphic work and paleobathymetric estimates allow a fairly comprehensive understanding of ages and paleodepths to be assembled by assuming a broadly similar depositional history for Sites 966 and 967 and taking a composite view of data from the two sites. In particular, the preserved early Miocene shallow-water limestones from Hole 966F (68-298 mbsf) complement the finding of early Oligocene pelagic limestones recovered at Hole 967A (138-
$167 \mathrm{mbsf}$ ). For further details of age and paleobathymetric estimates, see Spezzaferri et al. (Chap. 2), Premoli Silva et al. (Chap. 30), and Spezzaferri and Spiegler (Chap. 10), all this volume.

\section{METHODS}

\section{Subsidence Calculations}

To decompact the measured sediment thicknesses, I used the algorithms of Sclater and Christie (1980). In brief, the calculations involve numerical use of the empirical porosity vs. depth relationship discussed above to restore sediment thickness at the time of each dated horizon. As discussed above, incipient collision of the Eratosthenes platform with the Cyprus margin involves dynamic flexural deformation, and the assumptions of backstripping (Steckler and Watts, 1978) render it an inappropriate analysis technique. Instead, curves presented in Figures 5 and 6 show total subsidence of the reference surface (defined above) through time, corrected for sediment compaction. The vertical bars shown in Figure 5 and 6 reflect the range of the minimum and maximum values of the estimated paleobathymetry (c.f., Figs. 3 and 4), and the horizontal bars represent the range of numerical ages based on biostratigraphic data. In general, the age range for each dated horizon was taken to be the numerical age range of the biozone(s) (or portions thereof) assigned to the horizon. For example, if faunal evidence indicated that a horizon represented the upper N5 planktonic biozone, the numerical age range assigned would have been 19-20 Ma, whereas a horizon representing the P18 zone would have a range of 34-36 Ma. The time scales used in the conversion to numerical ages are discussed in Emeis, Robertson, Richter, et al. (1996; Neogene); Spezzaferri et al. (Chap. 2, this volume; Paleogene); and Premoli-Silva et al. (Chap. 30, this volume; Cretaceous). 


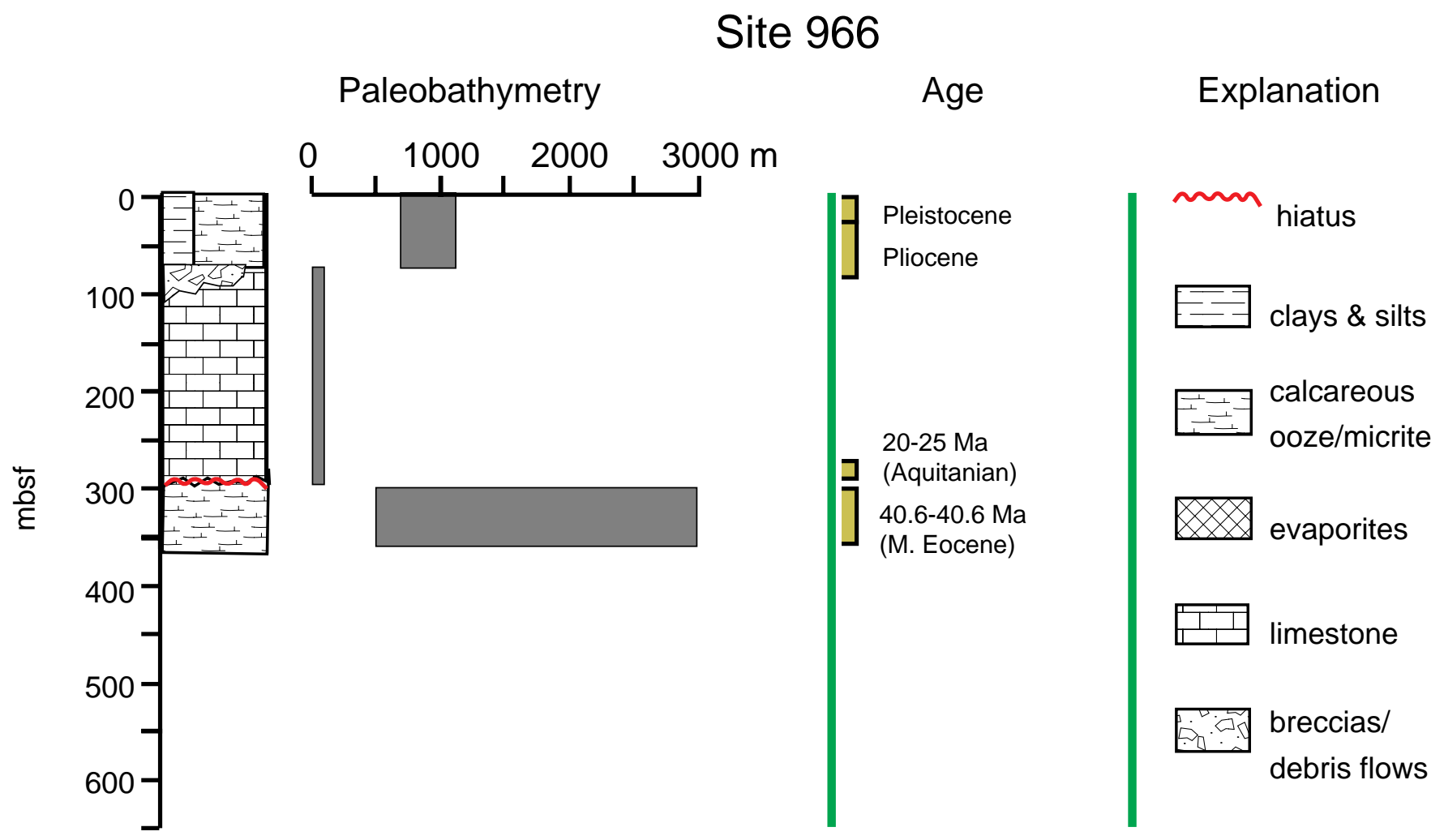

Figure 4. Data summary for Site 966, showing age, paleobathymetry, and lithology.

\section{RESULTS AND DISCUSSION}

Subsidence results for Sites 967 and 966 are shown in Figures 5 and 6, respectively. The Cretaceous through early Oligocene subsidence record for Site 967 indicates gradually decreasing subsidence rates through the period. This was accompanied by a progressive increase in water depth at the site from neritic to lower epibathyalupper mesobathyal ranges (c.f., Figs. 3, 5) accompanied by a decrease in sedimentation rate as the site became sediment starved. This paleobathymetric increase is consistent with a platform drowning event (Kendall and Schlager, 1981; Schlager, 1981; Neumann and Macintyre, 1985). The timing of this inferred drowning is consistent with rising sea level in the eustatic curve of Haq et al. (1988) and with other platform drownings in the region (summarized in Guiraud and Bellion, 1995). Although no pre-Eocene rocks were recovered at Site 966 (Fig. 4), the single Eocene-age data point on the Site 966 subsidence curve (Fig. 6) is consistent with subsidence results for Site 967. The overall pattern of Cretaceous through Paleogene subsidence at Sites 966 and 967 is consistent with thermal-decay driven passivemargin subsidence (Steckler and Watts, 1978; Sclater and Christie, 1980).

Neogene subsidence (Figs. 5, 6) departs from that typical of a passive margin. In particular, assuming that Sites 966 and 967 record approximately the same events (and thus data from the two sites can be combined), significant uplift of the Eratosthenes platform to inner neritic water depths occurred between the end of early Oligocene and Aquitanian time ( 30 to $20-25 \mathrm{Ma}$; Fig. 4). On the basis of subsidence results (Fig. 6), a minimum estimate of late Oligocene-early Miocene uplift is $\sim 1,000 \mathrm{~m}$. Available data do not permit resolution of details of middle to late Miocene subsidence. By early Pliocene time, Eratosthenes and its flanks were at water depths ranging from 700 to 2900 m. As seen in Figures 5 and 6, Pliocene-Holocene subsidence took place rapidly, as the lowest part of the early Pliocene succession already contains bathyal pelagic microfossils. Further subsidence took place after the late Pliocene, at least at Site 967, as benthic foraminifers there indicate upward deepening. Therefore, since the postMessinian re-establishment of open-marine conditions, subsidence rates have increased rapidly, which is characteristic of foredeep subsidence and uncharacteristic of passive-margin subsidence (Whiting and Thomas, 1994).

From the regional tectonic setting (see discussion above and elsewhere in this volume), eustatic sea-level variations are expected to be only a weak control on subsidence history. For example, the Messinian sea-level fall is accompanied in the subsidence curves by apparent uplift and subsequent deepening, but it is important to note that significant uplift at Site 966 had already occurred by early Miocene time (Fig. 6). Further, the magnitude of uplift at both Site 966 and Site 967 is much greater than that of the Messinian sea-level excursion. Therefore, with the exception of the Albian platform drowning discussed above, and the effects of the Messinian crisis, there appears to be little correlation between the subsidence history presented here and published eustatic sea-level curves.

\section{CONCLUSIONS AND IMPLICATIONS}

Based on the subsidence analysis presented here, the major conclusions of this study can be summarized as follows:

1. Cretaceous-Paleogene subsidence history supports previous assertions that the Eratosthenes platform represents a thinned, foundered sliver of continental crust, perhaps comparable to the Grand Banks of Newfoundland.

2. Between $\sim 30$ and $20-25 \mathrm{Ma}$, the Eratosthenes platform experienced a dramatic change in subsidence mode, marked by a minimum uplift of $\sim 1,000 \mathrm{~m}$. The overall timing of this uplift is consistent with that of acceleration in the rate of emplacement of the Troodos ophiolite on Cyprus (Robertson and Xe- 


\section{Site 967 Subsidence}

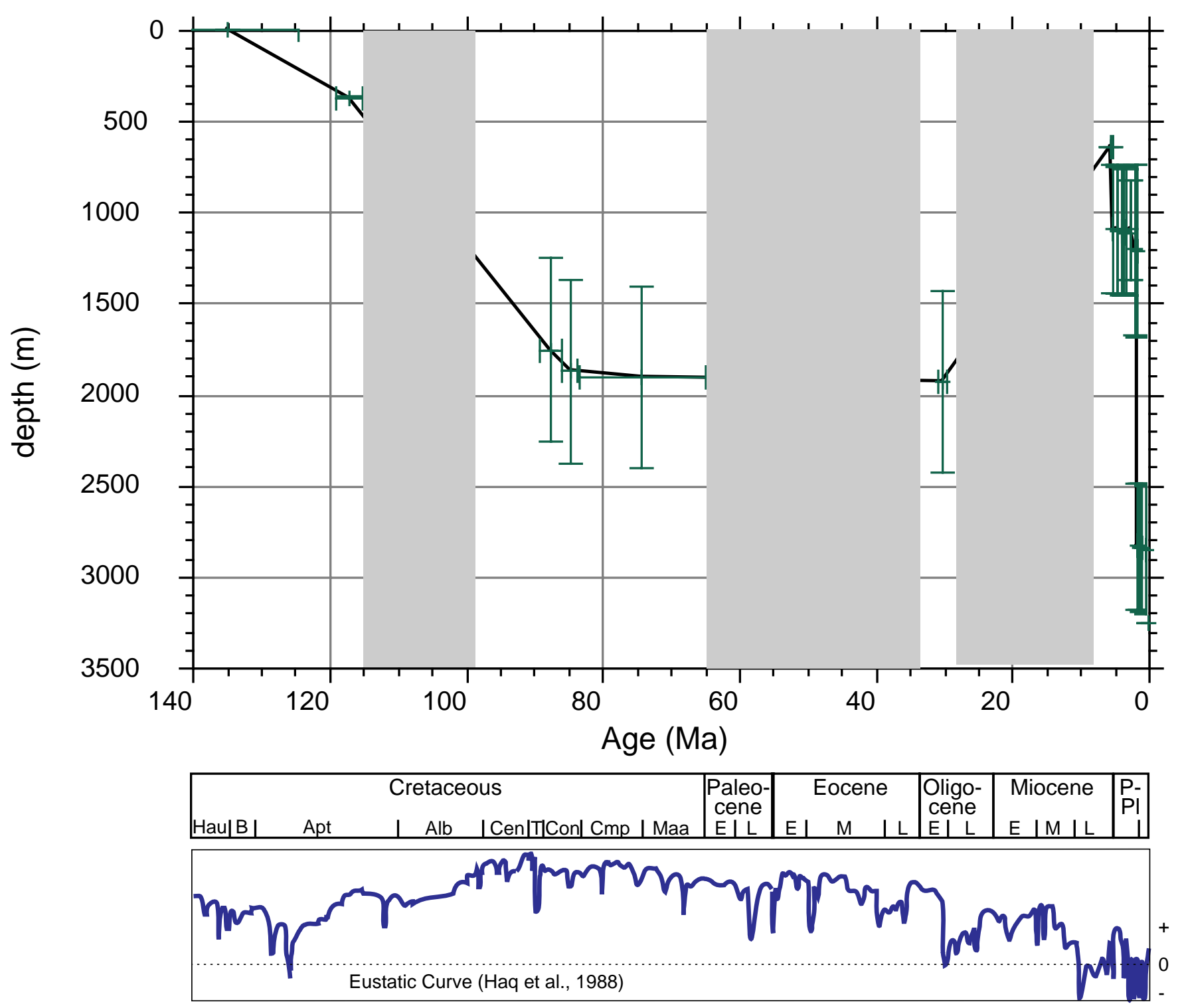

Figure 5. Total subsidence for Site 967. Eustatic curve time scale adjusted to that used in this volume. Gray pattern over curve indicates known hiatuses. Hau $=$ Hauterivian; B = Barremian; Apt = Aptian; Alb = Albian; Cen = Cenomanian; T = Turonian; Con = Coniacian; Cmp = Campanian; Maa = Maastrichtian.

nophontos, 1993; Robertson et al., 1995a), and thus the two processes are likely related. Further, rapid subsidence since early Pliocene time coincides with normal faulting, which confirms earlier suggestions that the Eratosthenes platform is undergoing breakup as it starts to descend down the Cyprus trench.

3. Eustatic sea-level variations are at best a second-order control on subsidence, with the exception of the Albian drowning discussed above.

\section{Flexure-Induced Subsidence and Uplift of Eratosthenes Platform}

The documented collision of the Eratosthenes platform with the Cyprus margin, and incipient subduction into the Cyprus trench, appears to represent the earliest stage of formation of a foredeep, which develops by large-scale thrust-fault emplacement (Jordan, 1981;
Beaumont, 1981). The transition from shallow-water carbonates to deep-water hemipelagic and terrigenous sediments can be compared with that observed on land in many accreted carbonate-platform slices (Robertson et al., 1997). Similar transitions from shallow- to deepwater sediments is seen in a number of Tethyan (e.g., in Oman) and other continental margins (e.g., S. Appalachians; Whiting and Thomas, 1994), and can be directly related to thrust and nappe emplacement. Rapid subsidence of Eratosthenes sites was accompanied by large-scale normal faulting, which is observed in Leg 160 site-survey seismic profiles and in cores (Emeis, Robertson, Richter, et al, 1996). This indicates that Eratosthenes lithosphere did not deform by simple flexure, but also underwent significant brittle deformation. This flexural extension is widely observed (Bradley and Kidd, 1991) and may be part of the explanation for late Oligocene-early Miocene uplift. While the cause of the observed uplift is unclear, the results presented here provide an important observational constraint for models of early-stage continental collision. 
Site 966 Subsidence

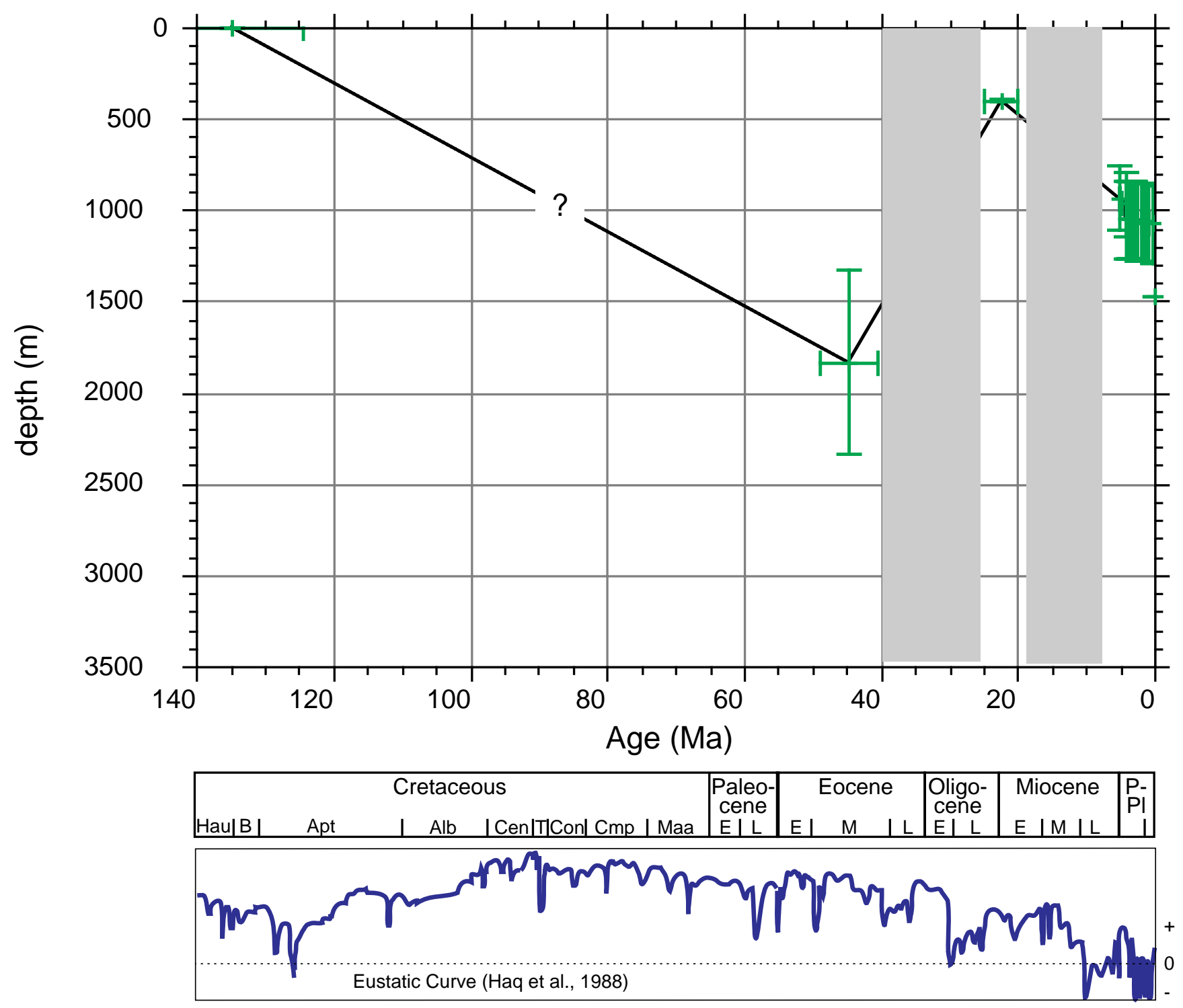

Figure 6. Total subsidence for Site 966. Eustatic curve time scale adjusted to that used in this volume. Gray pattern over curve indicates known hiatuses. Hau $=$ Hauterivian; $\mathrm{B}=$ Barremian; Apt $=$ Aptian; Alb = Albian; Cen $=$ Cenomanian $; \mathrm{T}=$ Turonian Con $=$ Coniacian $; \mathrm{Cmp}=\mathrm{Campanian} ; \mathrm{Maa}=\mathrm{Maastrichtian}$.

\section{REFERENCES}

Athy, L.F., 1930. Density, porosity and compaction of sedimentary rocks. AAPG Bull., 14:1-24.

Beaumont, C., 1981. Foreland basins. Geophys. J. R. Astron. Soc., 65:291329.

Bradley, D.C., and Kidd, W.S.F., 1991. Flexural extension of the upper continental crust in collisional foredeeps. Geol. Soc. Am. Bull., 103:14161438.

Clube, T.M.M., Creer, K.M., and Robertson, A.H.F., 1985. Palaeorotation of the Troodos Microplate, Cyprus. Nature, 317:522-525.

Dercourt, J., Ricou, L.F., and Vrielynck, B. (Eds.), 1993. Atlas of Tethys Palaeoenvironmental Maps: Paris (Gauthier-Villars).

Dewey, J.F., and Şengör, A.M.C., 1979. Aegean and surrounding areas: complex multi-plate and continuum tectonics in a convergent zone. Geol. Soc. Am. Bull., 90:84-92.
Doglioni, C., and Goldhammer, R.K., 1988. Compaction-induced subsidence in the margin of a carbonate platform. Basin Res., 1:237-246.

Emeis, K.-C., Robertson, A.H.F., Richter, C., et al., 1996. Proc. ODP, Init. Repts., 160: College Station, TX (Ocean Drilling Program).

Garfunkel, Z., and Derin, B., 1984. Permian-early Mesozoic tectonism and continental margin formation in Israel and its implications for the history of the Eastern Mediterranean. In Dixon, J.E., and Robertson, A.H.F. (Eds.), The Geological Evolution of the Eastern Mediterranean. Geol. Soc. Spec. Publ. London, 17:187-201.

Guiraud, R., and Bellion, Y., 1995. Late Cretaceous to Recent geodynamic evolution of the west Gondwonian, cratonic, Tethyian margins. In Nairn, A.E.M., Ricou, L.-E., Vrielynck, B., and Dercourt, J. (Eds.), The Ocean Basins and Margins (Vol. 7): The Tethys Ocean: New York (Plenum), 101-124.

Haq, B.U., Hardenbol, J., and Vail, P.R., 1988. Mesozoic and Cenozoic chronostratigraphy and cycles of sea-level change. In Wilgus, C.K., Hastings, B.S., Kendall, C.G.St.C., Posamentier, H.W., Ross, C.A., and Van Wag- 
oner, J.C. (Eds.), Sea-Level Changes? An Integrated Approach. Spec. Publ.?Soc. Econ. Paleontol. Mineral., 42:72-108.

Jordan, T.E., 1981. Thrust loads and foreland basin evolution, Cretaceous, western United States. AAPG Bull., 65:2506-2520.

Kendall, C.G.St.C., and Schlager, W., 1981. Carbonates and relative changes in sea level. In Cita, M.B., and Ryan, W.B.F. (Eds.), Carbonate Platforms of the Passive-type Continental Margins, Present and Past. Mar. Geol., 44:181-212.

McKenzie, D., 1978. Some remarks on the development of sedimentary basins. Earth Planet. Sci. Lett., 40:25-32.

Morris, A., 1996. Paleomagnetism and tectonics of the Mediterranean. In Morris, A., and Tarling, D.H. (Eds.), A Review of Paleomagmetic Research in the Troodos Ophiolite, Cyprus. Geol. Soc. Spec. Publ. London, 105:311-324.

Morris, A., Creer, K.M., and Robertson, A.H.F., 1990. Palaeomagnetic evidence for clockwise rotations related to dextral shear along the southern Troodos transform fault, Cyprus. Earth Planet. Sci. Lett., 99:250-262.

Neumann, A.C., and Macintyre, I., 1985. Reef response to sea level rise: keep-up, catch-up, or give-up. Proc. 5th Int. Coral Reef Congr., 3:105110.

Perrier, R., and Quiblier, R., 1974. Thickness changes in sedimentary layers during compaction history: methods for quantitative evaluation. $A A P G$ Bull., 58:507-520.

Piper, J.D.A., Moore, J.M., Tatar, O., Gursoy, H., and Park, R.G., 1996. Paleomagnetic study of crustal deformation across an intracontinental transform: the North Anatolian Fault Zone in Northern Turkey. In Morris, A., and Tarling, D.H. (Eds.), Paleomagnetism and Tectonics of the Mediterranean Region. Geol. Soc. Spec. Publ. London, 105:299-310.

Robertson, A.H.F., 1990. Tectonic evolution of Cyprus. In Malpas, J., Moores, E.M., Panayiotou, A., and Xenophontos, C. (Eds.), Ophiolites: Oceanic Crustal Analogues. Proc. Symp. "Troodos 1987," Nicosia, Cyprus (Geol. Surv. Dep., Minist. Agric. Nat. Resour.), 235-250.

, 1994. Role of the tectonic facies concept in orogenic analysis and its application to Tethys in the Eastern Mediterranean region. Earth-Sci. Rev., 37:139-213.

Robertson, A.H.F., Clift, P.D., Degnan, P., and Jones, G., 1991. Palaeogeographic and palaeotectonic evolution of the Eastern Mediterranean Neotethys. Palaeogeogr., Palaeoclimatol., Palaeoecol., 87:289-344.

Robertson, A.H.F., Dixon, J.E., Brown, S., Collins, A., Morris, A., Pickett, E., Sharp, I., and Ustaomer, T., 1996. Alternative tectonic models for the Late Paleozoic-Early Tertiary development of Tethys in the Eastern Mediterranean region. In Morris, A., and Tarling, D.H. (Eds.), Paleomagnetism and Tectonics of the Mediterranean Region. Geol. Soc. Spec. Publ. London, 105:239-263.

Robertson, A.H.F., Emeis, K.-C., Richter, C., Blanc-Valleron, M.-M., Bouloubassi, I., Brumsack, H.-J., Cramp, A., De Lange, G.J., Di Stefano, E., Flecker, R., Frankel, E., Howell, M.W., Janecek, T.R., Jurado-Rodriguez, M.-J., Kemp, A.E.S., Koizumi, I., Kopf, A., Major, C.O., Mart, Y., Pribnow, D.F.C., Rabaute, A., Roberts, A.P., Rullkötter, J.H., Sakamoto, T., Spezzaferri, S., Staerker, T.S., Stoner, J.S., Whiting, B.M., and Woodside, J.M., 1995a. Evidence of collisional processes associated with ophiolite obduction in the eastern Mediterranean: results from Ocean Drilling Program Leg 160. GSA Today, 5:213-221.

Robertson, A.H.F., Emeis, K.-C., Richter, C., Blanc-Valleron, M.-M., Bouloubassi, I., Brumsack, H.J., Cramp, A., Di Stefano, G.J., Flecker, R.,
Frankel, E., Howell, M.W., Janecek, T.R., Jurado-Rodriguez, M.-J., Kemp, A.E.S., Koizumi, I., Kopf, A., Major, C.O., Mart, Y., Pribnow, D. F.C., Rabaute, A., Roberts, A.P., Rullkötter, J.H., Sakamoto, T., Spezzaferri, S., Staerker, T.S., Stoner, J.S., Whiting, B.M., and Woodside, J.M., 1997. Collision-related break-up of a carbonate platform (Eratosthenes "Seamount") and mud volcanism on the Mediterranean Ridge: preliminary synthesis and implications of tectonic results of ODP Leg 160 in the eastern Mediterranean Sea. In Cramp, A., MacLeod, C. J., Lee, S.V., and Jones, E.J.W. (Eds.), Geological Evolution of Ocean Basins: Spec. Publ.-Geol. Soc. London 131:243-271.

Robertson, A.H.F., Kidd, R.B., Ivanov, M.K., Limonov, A.F., Woodside, J.M., Galindo-Zaldivar, J., and Nieto, L., 1995b. Eratosthenes Seamount, easternmost Mediterranean: evidence of active collapse and underthrusting beneath the Cyprus active margin. Terra Nova, 7:254-264.

Robertson, A.H.F., and Xenophontos, C., 1993. Development of concepts concerning the Troodos ophiolite and adjacent units in Cyprus. In Prichard, H.M., Alabaster, T., Harris, N.B. and Neary, C.R. (Eds), Magmatic Processes and Plate Tectonics. Geol. Soc. Spec. Publ. London, 70:85120.

Schlager, W., 1981. The paradox of drowned reefs and carbonate platforms. Geol. Soc. Am. Bull., 92:197-211.

Schmoker, J.W., and Halley, R.B., 1982. Carbonate porosity versus depth: a predictable relation for south Florida. AAPG Bull., 66:2561-2570.

Sclater, J.G., and Christie, P.A.F., 1980. Continental stretching: an explanation of the post-mid-cretaceous subsidence of the central North Sea basin. J. Geophys. Res., 85:3711-3739.

Steckler, M.S., and Watts, A.B., 1978. Subsidence of Atlantic-type continental margin off New York. Earth Planet. Sci. Lett., 41:1-13.

Thomas, W.A., and Whiting, B.M., 1996. The Alabama Promontory: example of evolution of an Appalachian-Ouachita thrust-belt recess at a promontory of the rifted continental margin. In Hibbard, J.P., van Staal, C.R., and Cawood, P.A. (Eds.), Current Perspectives on the Appalachian-Caledonian Orogen. Spec. Paper-Geol. Assoc. Can., 41:3-20.

Truffert, C., Chamot-Rooke, N., Lallemant, S., de Voogd, B., Huchon, P., and Le Pichon, X., 1993. The crust of the Western Mediterranean Ridge from deep seismic data and gravity modelling. Geophys. J. Int., 114:360-372.

Van Hinte, J.E., 1978. Geohistory analysis: application of micropaleontology in exploration geology. AAPG Bull., 62:201-222.

Whiting, B.M., Karner, G.D., and Driscoll, N.W., 1994. Flexural and stratigraphic development of the west Indian continental margin. J. Geophys. Res., 99:13791-13812.

Whiting, B.M., and Thomas, W.A., 1994. Three-dimensional controls on subsidence of a foreland basin associated with a thrust-belt recess: Black Warrior basin, Alabama and Mississippi. Geology, 22:727-730.

Woodside, J.M., 1991. Disruption of the African Plate margin in the eastern Mediterranean. In Salem, M.J., Sbeta, A.M., Bakbak, M., and Rida, M. (Eds.), The Geology of Libya: Symp. Geol. Libya 3, 6:2319-2329.

Date of initial receipt: 15 January 1997

Date of acceptance: 23 June 1997

Ms 160SR-039 